\title{
〉研供会校告 14
}

\section{ゆとりとやすらぎのある辰村計画を求めて \\ 一展菜土木学会辰村計画研究部会主催・唇村計画学会協替現地研修集会一}

藤 沢 和*

第10回の記念すべき現地研修集会（展莱土木学 会展村計画研究部会主催, 裳村計画学会協替) は, “ゆとりとやすらぎのある晨村計画を求めで

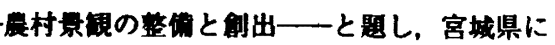
おいて,7月20日と21日の而日に踦り盛大（参加 人数802名)に開催された。

本誌をおかりしてその集会の概要を報告させて 戴く。

\section{概 要}

杜の都仙台に相応しい本テーマの主题 “展村景 毁” (Rural Landscape)については，最近全国的 な规模で語られ詥ぜられるようになってきている が、その中で研修集会は宮城県農政部を中心とし て開傅されたがそのブログラムは次の通りであ る。

1 宸村景覞について江崎陽一郎

2 総合保赛地鳌筑法の制定と 農山村地域の開発

3 水のある卧村風景

川嶋 久義

佐藤 俊郎

4 みどりの显钼の創造と保全

一西ドイッの展村における事例 を中心として一勝野 武彦

5 田尻町のまちつくくり蒋浦 枟藏

6 国営藤沢開拓事亲とまちづくり について 竹原昭雄, 宮本英昭

7 新しい時代のふるさと晨莱人佐藤 光雄 以上 7 譟題で，その概要を述べると（劷師の先 生方には卸容敖願いつつ) 次のようである。

「貫村貫镜について〕 江崎陽一郎撞師（宮城教育大学教育学部教授） は景䚋について次のように論じている。
「景観とは，人々の目に映ずる空間の有槏であ ク，換言すれば，层村景钼とは，その地域の自然 と宸業（技術を含む）と宸民や宸村に居住するも のの生活（道具・装昷, 施設を含む）とそのかか わりの䋧体，即ち好むと好まさるとにかかわらな いこれらの関係の耚体として，表現し認識されな ければならない。

澄んだ空気や山々の景色を，梅かな街並みや村 のただずまいを等々，ある地域の一つの表現や㑡 面として使われることは，その地域の生活主体を 抜きにした植民地的貫観（道切でないが，都市空 間が失ったものを求めたり㭪うための，地域住民 の生活の安定と向上とは別の経済効率や新争の原 理，外来者や旅人の感侮，勝手気ままな要求にも とづく地域開発の結果生ずるの意)を意味するこ とになり，强いては，贯観と深くかかわる地域計 画（手法・技術を含めて）を進める上でも好まし くない。

したがってこれと特に関保深い地域計画とは， 或る土地（地域）に住み生活（人間が人間として 生命を維持するためにかかわる，生産や消费の過 程=営み）している主体としての人々がその暮し

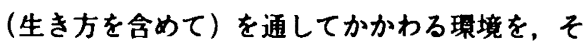
の人々にとってより好ましい方向に整えること， その結果が現状より更に好ましい人間存在として 展開される条件を，その方法と具体物を含めて創 造していくことである。

ここでいう主体とは，当然一人一人の個人であ る。それも，そこに住み生活している個人である。 このように主体を個人としてとらえた時にはじめ て人間と人間との閲係すなわち社会関係（例えば 加害者と被害者の関係）が明確になってくる。

また地域は，更に大きな広い地域とのかかわり の中で好ましさを可能にし，主体としての個人個

* 研修集会担当幹事 (明治大学農学部助教授) 
人にも豊かさを招来することは明らかである。そ の意味において国土（広域）を地域（そこに住み 生活する人々を含めて）の計画整備（住みよさ） とどうかかわらせて認識するかが地域の在り方を 具体的に拘束する。ある意図をもった国土計画の ために地域が奉仕させられたり，即ちある地域の 開発，整備をそこに住む人間とその生活をも含め て，手段とする立場の誤りを指摘したい。

要言すれば，農村の人々の生きる条件，即ち生

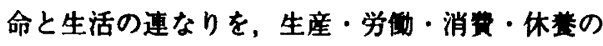
社会でのしくみを明らかにするなかで，宸村の生 活赀間を，人間と自然と社会との合法的な関係で 正しく認識していくという立場を明確にしておき たい。

おわりに，農村罯钼についてを地域と地域のも つ力及び地域の教育の梘点から述べたのは，景観 が，地域がそこに住み生きている人々にとってど うあるべきかを，その地域の持つ問題の掘下げゃ 住む人々の棁みや喜びに根ざした長い間の解決へ の努力とその成果の上に立って明確にすることな しの表層的詈観として理解されたり，地域つくり にあたってそこに住む地域住民の皘極的で主体的 なかかわりが得られないままでの移入的景钼とし てとり入れられることは，結果としてめずらしい 古い変わったものなどといった衙動的興味の対象 としての農村景観, 即ち景観としての存在（それ をもためもののための）となり，地域のもつすば らしい価値の絵てを留失させてしまうことになる ことへの危ぐからである。としている。 発」

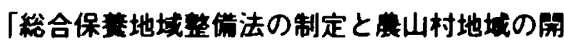
宸林水産省の川鴄久義讙師（棬造改善局建設部 設計課長補佐）は，最近の動向を次のように述べ ている。

「近年の国民の余暇時間の增大・生活㥞式の変 化などに伴い，余䝢活動の活発化，多㤦化が進行 しており，既に民間事業者等を中心として，各地 で従来の観光地とは異なるタイブのリソート施設 の整诸が進められている。

このような中で，第108国会において昭和62年 5 月22日，国民の多粎な余昵活動に応えるととも
に，第三次産業の振興を梃子とした地域の活性化 をめざすための総合的な政策的措置を講ずる「総 合保養地域整備法」が成立した。

同法は，昨年 5 月から11月にかけて，農林水産 省をはじめ, 国土庁，通商産業省，運輸省，建設 省, 自治省がそれぞれ独自に発表していたリソー 卜整储に関する粠想を一本にとりまとめた 6 省庁 共管の法律である。

この中で，農林水産省の果たすべき役割は大き く，農山村等の発展にも大きく貢献する制度とし て, 従来の農林水産省行政を一歩進めた独自の位 圈付けを持つものである。

現在, 宸業は，政策的保護のあり方，農産物の 洒格・流通のあり方，内外価格差と輸入规制のあ り方等について，国内外からの爰しい批判を受け

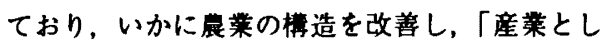
て自立し得る蜄業」の確立を図ることができるか が大きな課題になっている。

また，一般経済情疑が敞しい中にあって，首都 圈への経済活動集中頃向が強まっており，農山村 等における地方経済がとり残される状況が生まれ てきている。

このような状況の中で, 従来の工業萛入型とは 異なる, 地域の自然, 産業, 文化等を生かした形 でのリソート地域の整借は，䟦山村地域における 新たな就業の場の碓保，晨林産物等の消费の拡 大, 都市と展山村の情㫰の交換等を通した人材の 育成等, 地方の活性化の一手段として大いに期待 されているところである。

また，総合保養地域法の成立以来，リソート地 域開発フームに一届の拍車がかかっており，現在 東京都を除く46道府県より70を越える地域より整 備の要望がでている。

一般経済情繁が敞しく工業開発による地方の活 性化が困難な状況にある中にあって，地方整䚚の 目玉として本法への期待の大きさは理解できるも のであるが、リソート整備を通した地域の発展 は，需要を引き付ける蛙力をいかに設定するか， 農林業を始めとする地場産業の振興にいかに結び つけるか, 地域住民等の参加がいかに得られる か，多皟な初期投资にいかにして耐えるか等程々 な課題をかかえている。従って, 相当綿密な調査 
に基づいた計画の策定が求められ，農山村地域の 整傹を担当してきた農業土木技術者等の経験を十 分生かし, 計画への稳極的な参加が求められてい る。としている。

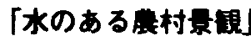

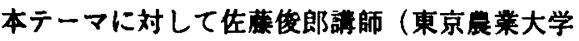
晨学部教授）は次のように述へている。

「都市にあこがれをもって集まり，都市を過密 にし，拡大した人達によって，ある時間をおいて 農村がみなおされるようになる。都市に生活する 多くの人達は，都市は生活に便利であるが，自然 がないという。人間の生活には，利便さだけでは なく，自然へのあこがれがあり，生活の中に自然 が必要なのであろう。

都市生活にあきたらず，晨村をみている人達の 多くは，晨村は自然であり，自然の中に宸村があ ク，良村の中に自然があると考えているようであ 万。

しかし「自然をととうとらえるかにもよるが, 山奥に敬在する山村は別として，集落を成し或い は扇状地に散在する点状村落の地域でも，本源的 な意味においての自然は存在しないのである。人 亩は，純粋な自然の中での生活はできないのであ って，それぞれの自然立地の中にあって，独自の 風土をつくり，地域に合った文化を形づくり発展 させるのである。とくに，わが国のように水田を 中心とした晨耕社会，展耕文化を基碳として発展 してきた境合には, 宸地・晨村の形成過程から も，河川という河川には例外なく人手加加えられ ているし，晨地も水田と㚼地とを問わず，ことご とく人工的につくりあげてきたものである。そし

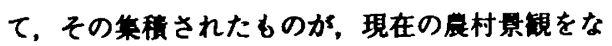
しているのである。

さて晨村の贯钼は，景钼として人工的に造形さ れたものではなかった。水田にしろ，㚼地にし ろ,また水路や道路にしろ, 人工的な所産ではあ ろが，それは農業を営む展村の機能として形成さ れたものであった。従って，それらは，展業生産 と晨業を営む農民とその集団である村々の生活の ために形づくられたものである。层業の様式や土 地及び水利用をはじめ，晨民の生活に至るまで，
地城の歷史的風土によってっくりあげられたもの であったから，農村の䍗钼は風土を離れて存在す るものではなかった。これは，地域の自然立地が 大きなかかわりをもっていた。この良し悪しは別 として,「自然改造」ということが言われるよう になって以来，わが国の社会は方向を変えて進展 した。そこには我田引水的な自己中心に微した経 済最優先の思想があった。歴史的過程を経て発展 してきた風土的思考はうとんぜられ，農村の景钼 にも変調をみるようになった。農村に侵入した都 市化は，晨地をスプロール化し，用・排水路を分 断し，水澌を污染・污濁し，過密な雑居地をつく ク，田園都市といわれるようなものとは程遠い地 域を形成してしまった。都市化のすすんた，わが 国の多くの譬村は，現在このような中におかれて いる。そこでの宸村䑁観は，自然からも風土から も遊䴩した存在となり，歴史をもたない景観を呈 している。

では，農村の景観を如何に発展させたらよいの かについて考えてみると，時の流れ，時代の変逜 にともなって, 社会の諸相も, われわれの生活も 変化するのは当然である。従って，農村の景観に も変化が生ずる。問題は変化の内容である。蛸が 自らの足を食うような变化であってはならない。 経済優先の指向も結粠であるが，ともどもに発展 しなければならない。他の犠牲の上に立脚した発 展であってはならない。すべてはわれわれの，生 活がその中心でなければならないからである。 前にもふれたように，わが国との対比では，水の ないといったほうがよい晨村も世界には多く存在 する。しかし，わが国は自然立地に恵まれ，宸村 と水とは，きりはなしては考えられない関係にあ る。水があるが故に，農村の景観を㻋外するよう なことがあってはならない。景锶は，われわれの 生活を洞すものであるから，水も，水にかかわる 施設も，組織や制度を通してのその維持・管理 も，地域の自然・風土にふさわしい特徵あるもの として, 或いは保持し，或いは発展せしむること が，われわれに課せられた今日的な責務である。」 としてる。

「緑の贯钼の創造と保全」一西ドイッの農村にお 
ける事例を中心として一と题し勝野武彦講師（日 本大学農獣医学部助教授）は次のように述へてい 万。

「西ドイッは詈観 (Landschaft) について，苦難 の末制定に至った連邦自然保護法 (Bundesnat urschutzgesetz-1976)があり，これは瓄境破堙， 自然破壇を，一早くくい止め，全国土レベルで統 一ある自然保蕞と景稩の保全に関する法律を産み だした。この法律と同時に西ドイツの臬邦土地改 良法 (Bundesflurbereinigungsgesetz) も改正されて おり，その中には農村の累钼や自然の保讙，保全 に関するものが多い。

また，都市の生活璄境か悪化する中で，西ドイ ッでは週末レクリエーションや長期休睱を宸村で 過ごす人達が最近增加しているし，農村側も“わ が村は美しぐといったコンクールを通じて蕽村 整備，集落整備をより分かり易く，理解を得なが ら進めている。伝統的な集落形態から屋根や壁に 至るまで検討し，また貧化する自然資源の回復を 積極的に図ったり，緑㖹かな落ち着いた，洞いの あるトータルで安定した宜村にしようと努めてい る。

西ドイッは日本と異なり，比较的楥傾斜や平坦 部も多く，国土全体の中で㫳地の占める比事もわ が国のそれより大きい。それだけ人為的影番も永 く，大きく受けてきており，自然の澌も低下した とされている。

村落美化の歴史は古く，18世紀まで逆のほる。 特に南ドイッ, バイエルン地方は西ドイッの美化 運動発祥の地でもあり，以前から地域，地区（町 村や集落）の独自性，独立性を示すものとして位 置ついいている。現在では「わが村は美しく」とい う国レベルの村落美化コンクールがあり，晨家集 落内や地域内宸地も含め, 村落全体の美しさを䅧 っている。伝統的な民家形癿，集落形態や地区七 ンターのファサード，歷史的建物，事物，國場で の文化的贯観（農菜生産の中で培われ，維持され てきたもの）構成要素など皘極的に保全修復して いる。集落内整僻では広場, 集落内道路, 水路な ど生産・生活の近代化による改善と同時に古くか らの伝統的笨造・素材・デザイン，そのトータル なものとしての褁観の保全と調和を図っている。
西ドイッの晨村におけろ緑を中心とした贯観の 保全と創造に閔係する考え方で最も重要な点は， (1)宸地の占める比率が極めて高いこと，(2)単に鹿 業生産だけで展村または景観が語れないこと，(3) 宸地内に多くの莗重な自然資源，文化的资源が多 いこと，(4)保全保䛰だけでも十分でなく，新たに 利用规制や用地礁保により質の高い本来の自然を 創造して，量的䆩的に鄷かにしようとしているこ

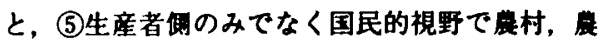
地を捉えていること、などが挙げられる。

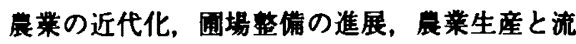
通その国際化，機械化・化学化の進展，それぞれ の側面から見ればわが国も類似している。しかし 基幹作目の逗いや晨地比率の量い，人口定住梯態 の違いなと異なる部分もまた極めて多い。

しかし, 生活, 生産空間としての展村でのより 䇺かな自然は科学的視点は言うに及ばず，住民の 快迹住空間の梘点からも，これまでに失った緑の 自然的・文化的累钼要素の復元・創造・保全は重 要である。農莱はあくまでも国の食䊓確保の使命 を持つと同時に，これまで承々として繶けられて きた農業生産と自然との調和ある進展を具現化し てきている。これまで進められてきた戒場整储の 内容を豊かにし，晨業施設の個々のデザインの幅

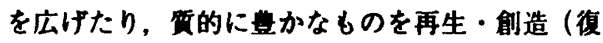
元）して行くことは，それ程困傕なことでは無 い。ファームボンドや用排水路，農道，その他の 農村の各種億䟝，いずれの場合もそのことが言え よう。展村の整然とした落ち着いた，鬥いのある 住空間，生産空間は多かれ少なかれ土地利用规制 を伴う。新たに作られた集落整備法や関臬法令等 により，既存集落とその周辺が稆序だって整储さ れ，農用地内と美しいコントラストを作る一方で 農用地も落ち着いた，伝統的景镜を宿しながら 個々の地域の独自性，特徽を表現している，そj いった䬤村が生まれてくることを長い目で期待し たいし，作り出して行かねばならないだろう。」 としている。

\section{[田尻町の町つくり」}

萧浦耘藏粪師（宮城県田尻町長）は将来の町づ くりについて次のように述へている。 
我が町は擘業立町であるが，農業を取り巻く㻴

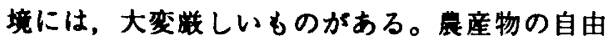
化, 娍反や転作对策，後継者不足，コス卜低隇な と、いずれも地域の発展を阻害する深刻な問題で ある。このような時代にこそ, 誤りのない目で,

榩村が選択すべき道を見つめていかなければなら ない。

私たちが暮らす田尻四は，北上川系の江合川流 域が広がり，栗駆山・船形山など奥羽山㹸の広大 なプナ林（1.5万ha）から流れ出る量富な水に惠 まれ，町の中央には，J R 東北本線が走り，明治 41年12月には田尻駅が開業され，来年には政令指 定都市としてスタートする人口88万人の仙台市ま でわずか50分の通勤，通学圈内にある。

東北新幹線古川駅から東へ $15 \mathrm{~km}$, 東北概貫自動 車道古川インターチェンジから車で20分という位 絔にある。

町の晨羓租生産皟は，107億円で，県下の町村 では 1 位，市を含めた県全体でも 3 位で，それを 支える耕地は，水田344ha，畑511 haで，耕地比率 は60.6\%である。

将来に向けて具体的に進めている基礎づくり

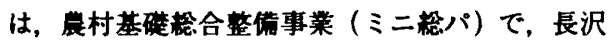
地区，大貫地区，小塭地区，大沢地区と進めてい 万。

今，長沢地区は完了し，大貫地区は本格的な工 事に取り組んでいる。

今までの晨村づくりは，道路のみ，國場のみ、 なと事業毎に単品として進められてきたが，集落 の暮らしも，生産基盤も螕合的に整销するという 方向になってきている。

私たちか戦後、ランフ生活から電気をつけたと き，天の岩戸が開いたとみんなでバンザイをし た。ランブからの開放の一瞬はいかにうれしかっ たか、経験した人しかかからない。戦中，腹が減 った時食へださつま苹のうまさは筫乏なるがあえ に自然に食べることの喜びを知った子供達。今そ れぞれが大人になって，水田を整销し，土をつく ク，水田の滅びは国の滅びに通ずると信じながら 人間の生命にかかわる食精を供給する産業と共に 生きている。また，水資源，緑地など環境を守 ク，きれいな水，きれいな空気，きれいな食べ物
がある処に，健康的な新しい生命が継生する。国 民の揵康のために，どれだけ農村が必要な処か， そこをどのような形で整储し，どのような機能を 高めて国つくりを進めて行ったらよいのか，大切 な基碳づくりは今からだと考えている。

〔国営霜沢開拓事業とまちつくり」

国営藤沢開拓事業に対し，宮本英昭講師（東北 甚政局藤沢建設事業所開発計画課長) は次のよう に述べいる。

「尨山村地域の町づくりは，第 4 次全国総合開 発計画に示すように「それぞれの地域が個性を生 かしつつ, 活性化を図るため、都市との交流によ って掁興」することが，不可欠である。

地域の活性化は地域自らの創意工夫と独自性を もって，地域間との存在を新うことにより成し遥 げられる。岩手県藤沢町は「みんなの藤沢, みん なでつくろう」を合言葉に，21世紀を展望した 「活力ある町, 心安まる町, 自立する町」をス口 ーガンとし独自の町づくりを進めている。

その中にあって国営藤沢開拓建設事業は，産業 の振興による䊦かな町「農エテクノタウン」建設 のため，自然資源を有効に活用して町の基幹産業 である農業を再編成し，生産性の高い農業を目指 して建設が進められている。

その町, 藤沢町は岩手県の南端に位置し, 宮城 県に接した北上山系最南端の西斜面丘陵地带にあ る。西端を北上川が貫流しており，東西に延びる 県境を底辺としてほほ三角形をなし，他町村との 境界は河川又は山稜によって分かれている。

町の面積は122.610でその60\%は山林であり， わずか20.3\%の耕地は北上川支流浻いに開けて， 68余の集落か点在している。

気象は宮城県北部と相通し, 年平均気温 $10.7^{\circ} \mathrm{C}$ で岩手県内で最も温暖な地域に属しているが，小 盆地を形成しているため年間を通じて寒暖の差か 比較的大きく，年平均降水量は $1,064 \mathrm{~mm}$ と少ない。

人口は昭和 30 年 16,398 人とピークに達し, 昭和 45年 12,561 人と $23.4 \%$ 隇少し，急激な過踈化とな り, 基幹産業である農業も衰退の一途をたどっ た。

そこで昭和 46 年 4 月過疎地域の指定を受け，町 
民は過亦からの脱却と自治崩榬の危機感に対する 共通の認識高まり，むらおこし気運が酸成され， 昭和49年「みんなの藤沢みんなでつくろう」を合 言葉として町民総参加のまちづくりを進めた。町 民総参加のまちづくりを進めるため，全町に43の 自治会が組織され，自分達の地域は自分達の力で よくする住民自治の精神から，集落每の掁與計画 がまとめられ，町の未来像を明確にし，町の総合 開発篗想策定へと発展していった。町はこれらの 自治会活動を支援するため，町倳員全員を「地城 分担性」として配廂し，町民赭参加のまちづくり を推進している。

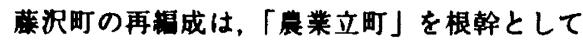

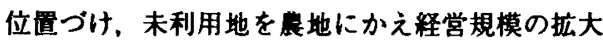
を図り，既耕地のかんがい施設の整備を行うと共 に，高速交通時代に対応した広域基幹宸道等も尊 入する計画も立案し，宸村理境整储の事業も併せ て実施することにした。現在これ等の事業は国営

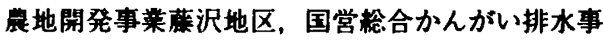
業東整井地区，県営かんがい排水事業藤埼地区及 ひ広域営展団地農道整销事業東磐井地区として進 められている。」と述へている。

「新しい時代のふるさと展業へ」一宮城の土地

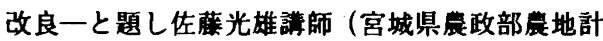
画課課長）は次のように述べている。

「新しいふるさとつくりりという言葉を地域論 に使ったのはおそらく，わか宮城県の山本壮一郎 知事が全国で初めてである（昭和47年）と思われ る。新しいふるさとづくりの基本理念は，美しい 自然や，ふるさとに伝わる良き伝統，文化を大事 にしながら，物心共に業かな生活ができる地域社 会 “定住の場”をみんなが费えて，人間が人間ら しい生活を追求し得る21世紀に向けての新しい地 域づくり，県土づくりを進めていこうというもの である。

この計画の中で，来るべき21世紀に向けての本 来の展業の発展方向が示され，創意と工夫に富 み，高度な技術・情報システムを活用した多彩で 生産性の高い農業としての発展を図り，新たな二 ースを創出する新時代の昔業への転換を図ること とし，このための基碳条件である農業基盤の整備
を総合的・計画的に推進することとした。

また，農村は，食粨の安定供給の場であると共 に，美しい自然景钼や，僼かな緑の空間を提供 し，人々にやすらぎと想を与える場として社会の 安定に寄与している。

しかし，近年の農村における萧業化，混住化， 高龄化の進行は，地域連带感の希薄化や諸资源の 共同管理機能の低下をもたらし，長い歴史に培わ れた宸村环境か，利便性や効率性の钼点から破壤 される危険性がある。

このため，美しい宸村の景锶保全・整備に配虑 しつつ快適な生活謤境基盤を宸莱生産基盤との調 和のとれた形の鳌備か課題となっている。

宮城県の農村の照観は，広大な農地と点在する 集落が織りなす独特の空間から成っている。莀村 には監かな自然に囲まれた人間的な暮らしが残っ ている。農村は生産の場であると同時に生活の場 でもあり，また都市の人々の故唧でもある。農村 のもつ自然の美しさ，いわゆる自然と調和のとれ

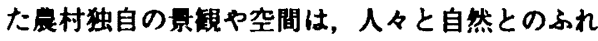
あいの場として保全, 整埆されることが大切であ る。

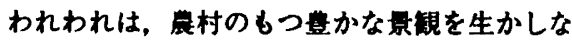
がら，農業生産基盤の整储を皘極的に推進し，21 世紀農羓を担う恳力おる農村を創造しなければな らない。」としている。

\section{まとめ}

以上で，第10回展村計画研究部会現地研修集会 の報告は終了するが，本研修集会に全国より参加 された方々は約800人で，その中に女性も参加さ れて居られた事と, 各地方公共団体で第一線で活 賈されている若い方々が多かったことは，研修集 会の盛況を支える一貫であったと思う。

さて，本研修集会の課題である “景観”につい て，意見百出したか，その目指すものは，共通点 が多く見られたものと思われる。そして，本テー マは今後の農村計画にとっても增々重要課題, 話 題になっていくものと思われると同時に，本研修 会集会がその碳石の第一歩となったものと確く信 じている。 